\title{
Charactrization of Biological Activities of Rehmannia g/utinosa Extracts
}

\author{
Young-Je Cho*
}

School of Food Science \& Biotechnology / Food \& Bio-Industry Research Institute, Kyungpook National University, Daegu 702-701, Korea

Received April 13, 2012 /Revised July 7, 2012 /Accepted July 14, 2012

\begin{abstract}
The content phenolic compounds in extracts from Rehmannia glutinosa was the highest in $40 \%$ ethanol extracts as $5.1 \pm 0.2 \mathrm{mg} / \mathrm{g}$. DPPH scavenging activity of $R$. glutinosa extracts was high in water extracts and $40 \%$ ethanol extracts as $85 \sim 93 \%$, ABTS radical cation decolorization of water extracts and $40 \%$ ethanol extracts was about the same as $55 \sim 62 \%$, antioxidant protection factor (PF) was confirmed in water extracts and $40 \%$ ethanol extracts as 1.6 1.9 PF, and TBARs of water extracts and $40 \%$ ethanol extracts were concluded to have the similar antioxidant effects. The hypertension inhibitory activity of water extracts and $40 \%$ ethanol extracts from $R$. glutinosa indicated the activities as $87.2 \%$ and $81.1 \%$, anti-gout activity was determined very low in $R$. glutinosa extracts and antimicrobial activity against skin microorgasm was confirmed, and tyrosinase inhibitory activity was determined as $70.2 \%$ in $40 \%$ ethanol extracts, it was expected the whitening effects in $40 \%$ ethanol extracts. The elastase inhibitory activity which are related to the wrinkle cause was observed in water extracts and $40 \%$ ethanol extracts as $76.2 \%$ and $57.2 \%$. The hyaluronidase inhibitory activity to $R$. glutinosa extracts was observed weakly in only $40 \%$ ethanol extracts of $200 \mu \mathrm{g} / \mathrm{ml}$ phenolic content as $5.1 \%$.
\end{abstract}

Key words : Biological activities, functional food, functional cosmetic, Rehmannia glutinosa

\section{서 론}

현대의학의 발전과 더불어 동양의학에도 많은 관심을 가지 게 되어 한의학 내지는 전통의학에서 주로 사용되던 약용식물 자원로부터 신약 성분들을 개발하려는 연구가 활발히 이루어 지고 있다. 최근 약용작물의 2차 대사산물들이 생체에서 나타 내는 생리활성들에 대한 연구가 활발히 진행되고 있고 $[18,23,34]$, 약용식물자원에서 항알레르기, 항산화, 항균 및 항 생활습관병 등의 약리성 물질 탐색과 이들 유용성분을 이용하 려는 연구가 활발하게 진행되고 있다 $[3,36]$.

지황(Rehmannia glutinosa Liboschitz)은 현삼과에 속하는 다 년생초이며, 생지황 (R. Radix crude)을 황주, 백주에 넣고 주침 하여 증숙한 후 건조한 것을 숙지황(R. Radix Preparata)이라 고 하는데 숙지황은 보약, 빈혈 위장병, 산후쇠약, 뇌빈혈 등에 쓰인다[8]. 숙지황에는 glucose, fructose, galactose 등의 단당 류와 stachyose를 위시한 다양한 올리고당 및 다당류 들이 함 유되어 있으며, catalpol, vitamin A, arginine, mannitol, $\beta$ -sitosterol 등도 소량으로 함유되어 있다[5,30,31,32]. 숙지황에 대한 생리활성 연구로는 Jeong and Kim [16]은 숙지황이 streptozotocin 유발 고혈당 흰쥐의 혈당강하작용이 우수하였 다고 보고하였으며, Park [25]은 지황류의 수침액이 고혈압의 원인인 혈장 rennin의 활성을 감소시킴으로서 혈압저하 효과 가 있다고 보고하였다. 또한 숙지황의 제조방법에 따른 소화

*Corresponding author

Tel : +82-53-950-7755, Fax : +82-53-950-7762

E-mail : yjcho@knu.ac.kr
작용에 관한 비교 연구[24], 흰쥐신장조직 손상에 대한 숙지황 의 항산화효과[6], 숙지황이 남성생식세포 GC-1의 항산화에 미치는 영향 등의 연구[15]가 있으나 건강기능성 식품에 적용 시키기 위한 생리활성의 검색은 미흡한 실정이다.

따라서 본 연구에서는 전통한약재로 사용되고 있는 숙지황 의 생리활성을 검토하여 기능성 소재로 이용하기 위하여 숙지 황 추출물의 항산화효과, 고혈압, 관절염 억제 등의 기능성 식품활성과 미백, 주름개선, 항염증 등의 기능성 미용식품활 성 등을 살펴보았다.

\section{재료 및 방법}

\section{추출물의 조제}

숙지황 추출액은 숙지황 $1 \mathrm{~g}$ 을 물과 ethanol을 $0 \sim 100 \%$ 로 변화시키며 $100 \mathrm{ml}$ 를 첨가하여 shaking incubator (SI-600R, Lab Companion, Korea)에서 24시간 동안 상온에서 $150 \mathrm{rpm}$ 으로 용매별 추출을 시행하였으며, 추출 후 추출액은 10,000 $\mathrm{rpm}$ 에서 15분간 원심분리(Himac CR-21E, Hitachi, Japan)하 고 Whatman No. 1 filter paper로 여과하여 여액을 시료로 사용하였다[20].

\section{Phenolic compound의 정량}

시료 $1 \mathrm{ml}$ 에 95\% ethanol $1 \mathrm{ml}$ 와 증류수 $5 \mathrm{ml}$ 를 첨가하고 $1 \mathrm{~N}$ Folin-ciocalteu reagent $0.5 \mathrm{ml}$ 를 넣어 잘 섞어주고, 5 분간 방치한 후, $5 \% \mathrm{Na}_{2} \mathrm{CO}_{3} 1 \mathrm{ml}$ 를 가한 후, 흡광도 $725 \mathrm{~nm}$ 에서 1 시간 이내에 측정하여 gallic acid를 이용한 표준곡선으로 양 
을 환산하였다[12].

\section{항산화 효과 측정}

$\mathrm{DPPH}$ radical에 대한 소거활성은 Blios의 방법[2]에 준하여 측정하였으며, 전자공여능 $(\%)$ 은 1-(반응구의 흡광도/대조구 의 흡광도 $\times 100$ 으로 나타내었다. ABTS radical cation decolorization (ABTS)의 측정은 Pellegrin 등의 방법[26]에 의해 측정하였고, 저해율 $(\%)$ 은 1-(반응구의 흡광도/대조구의 흡광 도) $\times 100$ 으로 나타내었다. Antioxidant protection factor $(\mathrm{PF})$ 는 Andarwulan과 Shetty의 방법[1]으로 측정하였으며, $\mathrm{PF}$ 는 반응구의 흡광도/대조구의 비로 나타내었다. Thiobarbituric acid reactive substance (TBARs) 측정은 Burge와 Aust의 방법 [4]에 따라 측정하여 저해율(\%)은 1-(반응구의 TBARs $\mu \mathrm{M} /$ 대 조구의 TBARs $\mu \mathrm{M}) \times 100$ 으로 나타내었다.

\section{항고혈압 효과 측정}

Angiotensin converting enzyme (ACE) 저해효과 측정은 Cushman 등의 방법[10]에 의하여 행하였다. 즉, 반응구는 0.3 $\mathrm{M} \mathrm{NaCl}$ 을 함유하는 $0.1 \mathrm{M}$ potassium phosphate buffer $(\mathrm{pH}$ 8.3)에 기질로 $2.5 \mathrm{mM}$ hippuryl-histidyl-leucine 용액 $0.15 \mathrm{ml}$ 를 혼합하였으며, 대조구는 추출액 대신 동일 buffer $0.1 \mathrm{ml}$ 를 첨가하여 $37^{\circ} \mathrm{C}$ 에서 30 분간 반응시키고 $1 \mathrm{~N} \mathrm{HCl} 0.35 \mathrm{ml}$ 첨가 로 반응을 중지시킨 뒤 $3 \mathrm{ml}$ 의 EtOAc를 첨가하였다. EtOAc층 만을 취한 다음 용매를 증류시킨 잔사에 $2 \mathrm{ml}$ 의 증류수를 첨가 하여 효소에 의해 기질로부터 분리되어 추출된 hippuric acid 를 $280 \mathrm{~nm}$ 에서 흡광도를 측정한 후 표준곡선에서 양을 환산하 여 아래의 식에 의해 저해율을 계산하였다. 저해율(\%)은 1-(반 응구의 hippuric acid 생성량/대조구의 hippuric acid 생성 량) $\times 100$ 으로 나타내었다.

\section{항관절염 효과 측정}

Xanthine oxidase (XOase) 활성저해 측정법은 Stirpe와 Crote의 방법[29]에 준하여 측정하였다. 즉, 반응구는 $0.1 \mathrm{M}$ potassium phosphate buffer (pH 7.5)에 xanthine $2 \mathrm{mM}$ 을 녹 인 기질액 $3 \mathrm{ml}$ 에 효소액 $0.1 \mathrm{ml}$ 와 시료 추출액 $0.3 \mathrm{ml}$ 를 넣고 대조구에는 추출액 대신 증류수를 $0.3 \mathrm{ml}$ 첨가하여 $37^{\circ} \mathrm{C}$ 에서 30 분간 반응시키고 $20 \% \mathrm{TCA} 1 \mathrm{ml}$ 를 가하여 반응을 종료시킨 다음 $3,500 \mathrm{rpm}$ 에서 15 분간 원심분리하여 단백질을 제거한 후 반응액 중에 생성된 요산(uric acid)의 함량을 $292 \mathrm{~nm}$ 에서 측정하여 다음 식으로 저해율을 구하였다. 저해율(\%)은 1-(반 응구의 uric acid 생성량/대조구의 uric acid 생성량) $\times 100$ 으로 나타내었다.

\section{항균활성 측정}

항균활성 측정실험에 사용한 균주는 Staphylococcus epidermidis, Staphylococcus aureus, Escherichia coli, Streptococcus mutans, Helicobacter pylori를 사용하였다. S. epidermidis, S. aureus, E. coli 배양에는 nutrient medium (Difco. USA)을 사용하 였으며, agar plate 상으로 $37^{\circ} \mathrm{C}$ 의 incubator에서 $24 \sim 48$ 시간 동안 실시하였다[9]. Streptococcus mutans 배양에는 brain heart medium을 Helicobacter pylori의 배양에는 최적배지 (special pepton $0.5 \mathrm{~g}$, agar $0.75 \mathrm{~g}, \mathrm{NaCl} 0.25 \mathrm{~g}$, yeast extract $0.25 \mathrm{~g}$, beef extract $0.2 \mathrm{~g}$ 및 pyruvic acid $0.025 \mathrm{~g} / 50 \mathrm{ml}$ )를 사용하여 미호기성 조건을 유지시켜주기 위해서 $10 \% \mathrm{CO}_{2}$ incubator를 이용하였으며, incubator의 습도는 항상 $95 \%$ 이상 으로 유지하였고, agar plate상에서 배양은 $37^{\circ} \mathrm{C}$ 로 $48 \sim 72$ 시간 동안 실시하였다[17]. 항균활성은 배양 후 생성된 clear zone의 크기 $(\mathrm{mm})$ 로 항균활성을 나타내었다.

\section{미백효과 측정}

Tyrosinase 저해활성 측정은 반응구는 $0.175 \mathrm{M}$ sodium phosphate buffer (pH 6.8) $0.5 \mathrm{ml}$ 에 $10 \mathrm{mM} \mathrm{L-DOPA}$ 를 녹인 기질액 $0.2 \mathrm{ml}$ 및 시료용액 $0.1 \mathrm{ml}$ 의 혼합액에 mushroom tyrosinase $(110 \mathrm{U} / \mathrm{ml}) 0.2 \mathrm{ml}$ 를 첨가하여 Yagi 등의 방법[35] 에 따라 측정하였으며, 저해율(\%)은 1-(반응구의 흡광도/대조 구의 흡광도)×100으로 나타내었다.

\section{주름개선 효과 측정}

Porcine pancreatic elastase 저해활성 측정[33]은 기질로서 $N$-succinyl-(L-Ala) 3 - $p$ nitroanilide를 사용하여 $37^{\circ} \mathrm{C}$ 에서 20 분 간 pnitroanilide의 생성량을 $405 \mathrm{~nm}$ 에서 흡광도를 측정하였 으며, 저해율 $(\%)$ 은 1-(시료첨가군의 흡광도/대조구의 흡광 도) $\times 100$ 으로 나타내었다.

\section{Anti-inflammation 효과 측정}

Hyaluronidase (HAase) 저해활성 측정은 sodium-hyaluronic acid (HA)로부터 형성된 N-acetylglucosamine을 glucoxazoline 유도체로 변형시킨 후 $p$ dimethylaminobenzaldehyde (DMAB)로 발색시켜 흡광도를 측정하여 효소 활성을 측정하였다[7]. 저해율 $(\%)$ 은 1-(시료첨가군의 흡광도/대조구 의 흡광도 $\times 100$ 으로 나타내었다.

\section{결과 및 고찰}

\section{숙지황으로부터 유용성분의 추출}

시료로부터 유용성분 추출의 최적 조건을 확립하기 위해 ethanol 용매를 다양한 농도로 조제하고 이를 추출용매로 하 여 시료추출의 최적농도를 찾고자 하였다. 그 결과 Fig. 1 과 Table 1에서와 같이 $40 \%$ ethanol 추출물에서 $5.1 \pm 0.2 \mathrm{mg} / \mathrm{g}$ 으 로 가장 높은 phenolic compound 함량을 나타내었으며, 물 추출물에서도 $4.8 \pm 1.7 \mathrm{mg} / \mathrm{g}$ 으로 ethanol 추출과 비슷한 수준 


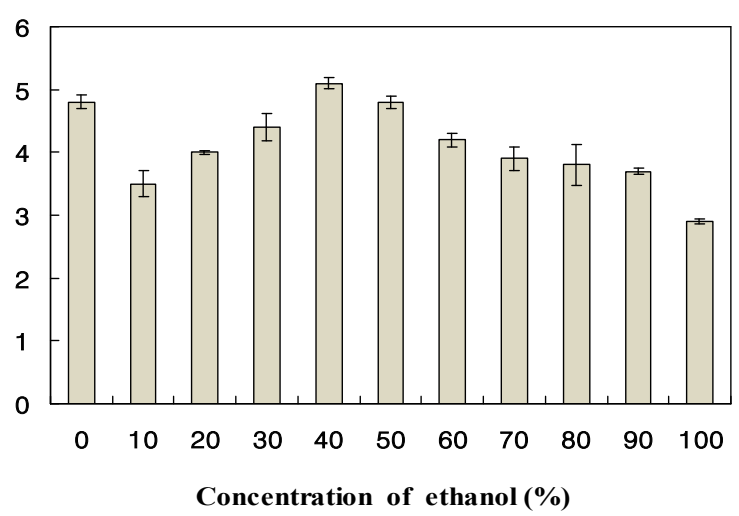

Fig. 1. The effect of ethanol concentration on extraction of phenolic from Rehmannia glutinosa. The data were expressed as the mean $\pm \mathrm{SD}(\mathrm{n}=6)$.

Table 1. phenolic contents of extracts from Rehmannia glutinosa

\begin{tabular}{ccc}
\hline \multirow{2}{*}{ Sample } & \multicolumn{2}{c}{ Phenolic content $(\mathrm{mg} / \mathrm{g})$} \\
\cline { 2 - 3 } & $\begin{array}{c}\text { Water } \\
\text { extracts }\end{array}$ & $\begin{array}{c}40 \% \text { Ethanol } \\
\text { extracts }\end{array}$ \\
\hline Rehmannia glutinosa & $4.8 \pm 1.7$ & $5.1 \pm 0.2$ \\
\hline
\end{tabular}

The data were expressed as the mean \pm SD $(n=6)$.

의 phenolic compound의 양이 용출되었다. 이는 허브의 경우 $50 \sim 60 \%$ 의 비교적 낮은 ethanol 농도에서 추출수율이 높게 나타난다는 $\operatorname{Kim}$ [19]의 연구 결과와 비슷하게 나타났다.

\section{숙지황 추출물의 항산화활성}

$\mathrm{DPPH}$ 라디칼 소거능 측정을 위하여 물과 $40 \%$ ethanol을 용매로 추출한 숙지황 추출물의 전자공여능을 측정한 결과 Table 2에서와 같이 물 추출물과 $40 \%$ ethanol 추출물 $200 \mu \mathrm{g} /$ $\mathrm{ml}$ phenolic의 농도에서 모두 85 93\% 의 높은 전자공여능이 확인되었으며, 물 추출물보다 ethanol 추출물의 효과가 더 높 게 나타났으며, 에탄올 추출물의 경우 $200 \mu \mathrm{g} / \mathrm{ml}$ phenolic의 농도에서 $92.7 \%$ 의 저해율을 나타내어 positive control인 BHT 의 $87.7 \%$ 보다 더 높은 전자공여능을 나타내었다. 또한 각 추 출물마다 농도 의존적으로 첨가되는 phenolic compound의 농도가 높아질수록 전자공여능도 더 높아지는 것으로 확인되
었다. 추출물들의 상대적인 항산화 측정은 hydrogendonating antioxidant와 chain breaking antioxidant 모두를 측 정할 수 있고 aqueous phase와 organic phase 모두에 적용이 가능하며 표준물질의 사용으로 추출물의 상대 비교가 가능하 도록 potassium persulfate와의 반응에 의해 생성된 $\mathrm{ABTS}^{+}$ free radical이 추출물속의 항산화 물질에 의해 제거되어 radical 특유의 색인 청록색이 탈색되는 것을 이용하여 ABTS radical cation decolorization을 측정한 결과 Table 2에서와 같 이 물 추출물과 $40 \%$ ethanol 추출물이 $55 \sim 62 \%$ 의 비슷한 수 준의 항산화효과를 효과를 나타내는 것으로 측정되었다. 숙지 황 추출물의 지용성 물질에 대한 항산화력을 측정하기 위하여 지질 산화과정에서 생성되는 peroxy radical과 반응하여 불활 성물질(inactive products)을 형성하고 그로 인해 free radical 에 의해 연쇄 반응을 중단시킨다는 $\beta$-carotene linoleate system을 이용하여 antioxidant protection factor $(\mathrm{PF})$ 를 측정 하였다[37]. 그 결과 Table 2에서와 같이 $200 \mu \mathrm{g} / \mathrm{ml}$ phenolic 의 농도에서 물 추출물과 $40 \%$ ethanol 추출물 모두에서 positive control인 BHT의 $1.2 \mathrm{PF}$ 에 비하여 1.6 1.9 PF의 매우 높은 항산화력이 확인되었고, TBARs는 물 추출물과 $40 \%$ ethanol 추출물이 비슷한 수준의 항산화 효과를 나타내는 것 으로 측정되었다. Duval과 Shetty [11]는 완두에 함유되어있는 phenol성 물질의 PF가 1.1 1.3 정도였다고 보고하였으며 본 실험에 사용된 숙지황의 항산화력이 더 우수한 것으로 나타났 다. 전반적으로 항산화효과는 ethanol 추출물이 물 추출물 보 다 높게 나타났으며, 이는 산화 촉진인자와 binding 하는 phenolic compound가 물 추출물보다 ethanol 추출물에 더 많 이 존재하기 때문인 것으로 생각되었으며, 향후 이들 phenolic compound의 profile에 대한 연구도 진행이 되어야 할 것으로 판단되었다.

\section{고혈압 억제(angiotansin converting enzyme 저해) 효과}

Angiotensin converting enzyme (ACE)은 renin에 의하여 생성된 angiotensin I 으로부터 $\mathrm{C}$ 말단의 depeptide를 가수분 해 시켜 혈관수축 작용을 갖는 angiotensin $\Pi$ 를 합성하는데 관여하며, 혈관이완작용을 가진 bradykinin을 억제시킴으로 서 혈압을 상승시키는 역할을 하는 효소이다[27]. 숙지황 추출

Table 2. Antioxidant activity of water and ethanol extracts from Rehmannia glutinosa

\begin{tabular}{|c|c|c|c|c|c|c|}
\hline \multirow{4}{*}{ Antioxidant assay } & \multicolumn{6}{|c|}{ Antioxidant activity (\%) } \\
\hline & \multicolumn{2}{|c|}{ Water extracts } & \multicolumn{2}{|c|}{$40 \%$ Ethanol extracts } & \multicolumn{2}{|c|}{ Positive control (BHT) } \\
\hline & \multicolumn{2}{|c|}{ Phenolic content $(\mu \mathrm{g} / \mathrm{ml})$} & \multicolumn{2}{|c|}{ Phenolic content $(\mu \mathrm{g} / \mathrm{ml})$} & \multicolumn{2}{|c|}{ Phenolic content $(\mu \mathrm{g} / \mathrm{ml})$} \\
\hline & 100 & 200 & 100 & 200 & 100 & 200 \\
\hline DPPH $(\%)$ & $79.3 \pm 1.3$ & $85.5 \pm 3.0$ & $80.2 \pm 1.6$ & $92.7 \pm 2.1$ & $84.0 \pm 0.1$ & $87.7 \pm 0.1$ \\
\hline ABTS (\%) & $49.6 \pm 0.9$ & $61.6 \pm 0.6$ & $44.2 \pm 0.8$ & $55.0 \pm 1.8$ & $5.8 \pm 0.1$ & $93.9 \pm 0.1$ \\
\hline TBARS $(\%)$ & $16.0 \pm 0.5$ & $22.8 \pm 2.1$ & $18.3 \pm 1.0$ & $26.7 \pm 0.7$ & $49.0 \pm 0.3$ & $85.3 \pm 0.3$ \\
\hline PF & $1.1 \pm 1.1$ & $1.6 \pm 0.6$ & $1.1 \pm 0.2$ & $1.9 \pm 1.1$ & $1.0 \pm 0.1$ & $1.2 \pm 0.1$ \\
\hline
\end{tabular}

The data were expressed as the mean \pm SD $(n=6)$. 
물의 $\mathrm{ACE}$ 에 대한 저해효과를 측정함으로서 항고혈압 효과를 살펴본 결과 Table 3 과 같이 $200 \mu \mathrm{g} / \mathrm{ml}$ phenolic의 농도에서 positive control인 captopril의 $68.4 \%$ 에 비해 물 추출물군에서 더 우수한 $87.2 \%$ 의 고혈압억제력을 나타내었고, $40 \%$ ethanol 추출물에서도 $81.1 \%$ 의 높은 저해활성을 나타내어 고혈압억제 제로서의 기능성 식품에 적용하기위한 산업화 가능성을 확인 시켜 주었다.

\section{관절염(gout) 저해효과}

Xanthine oxidase는 생체 내 퓨린대사에 관여하는 효소로 xanthine 혹은 hypoxanthine으로부터 요산을 생성하여 혈장 내 요산이 증가되면 낮은 용해성으로 인하여 골절에 축적되어 심한 통증을 유발하는 통풍(gout)을 일으킨다. 이러한 통풍의 치료에 사용되는 약물로는 hypoxanthine의 유사체인 allopurinol과 alloxanthine이 있는데 allopurinol은 xanthine oxidase에 강하게 결합하여 요산 생성의 최종단계에 관여하는 xanthine oxidase의 효소활성을 저해함으로써 요산의 생성을 억제하는 것으로 알려져 있다[28]. Table 4 는 숙지황 추출물의 xanthine oxidase 저해작용을 나타낸 것으로 물 추출물은 저해 효과를 나타내지 않았으며, $40 \%$ ethanol 추출물에서도 $3.3 \%$
의 극히 미약한 저해양상만 나타나 통풍(gout) 예방 및 치료를 위한 자원으로의 활용은 어려울 것으로 판단하였다.

\section{항균활성 측정}

숙지황 추출물의 항균효과를 측정하기 위하여 Staphylococcus aureus, Staphylococcus epidermidis, Escherichia coli, Streptococcus mutans 및 Helicobacter pylori를 사용하여 생육억제 효과를 측 정한 결과 Table 5에서와 같이 피부상재균인 S. aureus, S. epidermidis의 경우 $200 \mu \mathrm{g} / \mathrm{ml}$ phenolic 농도에서만 9.1 과 $9.6 \mathrm{~mm}$ 의 clear zone을 나타내어 항균력을 나타내었을 뿐 저 농도의 첨가군에서는 항균효과를 관찰할 수 없었으며, 충치균인 Streptococcus mutans와 위염, 위궤양 원인균인 Helicobacter pylori의 경우 농도에 관계없이 항균효과가 검출되지 않았다. 따 라서 숙지황 추출물은 피부상재균을 억제함으로써 피부 트러 블을 완화시킬 수 있는 화장료로 활용이 가능할 것으로 판단 하였다.

\section{미백효과}

Tyrosinase는 피부의 표피 기저층에 존재하는 멜라노 사이 트에서 tyrosine을 산화시켜 멜라닌의 생성을 촉진시키는 효

Table 3. Inhibition effect of water and ethanol extracts on angiotensin converting enzyme from Rehmannia glutinosa

\begin{tabular}{|c|c|c|c|c|c|c|}
\hline \multirow[b]{2}{*}{ Sample } & \multicolumn{2}{|c|}{ Water extracts } & \multicolumn{2}{|c|}{$40 \%$ Ethanol extracts } & \multicolumn{2}{|c|}{ Positive control (Captopril) } \\
\hline & $\begin{array}{l}\text { Hippuric acid } \\
(\mu \mathrm{g} / \mathrm{ml})\end{array}$ & $\begin{array}{l}\text { lnhibition } \\
\text { activity (\%) }\end{array}$ & $\begin{array}{l}\text { Hippuric acid } \\
(\mu \mathrm{g} / \mathrm{ml})\end{array}$ & $\begin{array}{l}\text { lnhibition } \\
\text { activity (\%) }\end{array}$ & $\begin{array}{l}\text { Hippuric acid } \\
(\mu \mathrm{g} / \mathrm{ml})\end{array}$ & $\begin{array}{l}\text { Inhibition } \\
\text { activity (\%) }\end{array}$ \\
\hline Control & $19.6 \pm 0.2$ & 0 & $19.6 \pm 0.1$ & 0 & $19.6 \pm 0.1$ & 0 \\
\hline Rehmannia glutinosa & $2.5 \pm 0.5$ & $87.2 \pm 5.9$ & $3.7 \pm 0.7$ & $81.1 \pm 7.3$ & $6.2 \pm 0.3$ & $68.4 \pm 2.4$ \\
\hline
\end{tabular}

Phenolic content were $200 \mu \mathrm{g} / \mathrm{ml}$. The data were expressed as the mean \pm SD $(\mathrm{n}=6)$.

Table 4. Inhibition effect of water and ethanol extracts on xanthin oxidase from Rehmannia glutinosa

\begin{tabular}{|c|c|c|c|c|c|c|}
\hline \multirow[b]{2}{*}{ Sample } & \multicolumn{2}{|c|}{ Water extracts } & \multicolumn{2}{|c|}{$40 \%$ Ethanol extracts } & \multicolumn{2}{|c|}{ Positive control (Allopurinol) } \\
\hline & $\begin{array}{c}\text { Uric acid } \\
(\mu \mathrm{g} / \mathrm{ml})\end{array}$ & $\begin{array}{l}\text { Inhibition } \\
\text { activity(\%) }\end{array}$ & $\begin{array}{c}\text { Uric acid } \\
(\mu \mathrm{g} / \mathrm{ml})\end{array}$ & $\begin{array}{c}\text { Inhibition } \\
\text { activity(\%) }\end{array}$ & $\begin{array}{c}\text { Uric acid } \\
(\mu \mathrm{g} / \mathrm{ml})\end{array}$ & $\begin{array}{l}\text { Inhibition } \\
\text { activity(\%) }\end{array}$ \\
\hline Control & $18.1 \pm 1.3$ & 0 & $18.1 \pm 1.3$ & 0 & $18.1 \pm 1.3$ & 0 \\
\hline Rehmannia glutinosa & $18.1 \pm 1.3$ & 0 & $17.5 \pm 2.2$ & 3.3 & $8.2 \pm 1.2$ & $54.7 \pm 1.3$ \\
\hline
\end{tabular}

Phenolic content were $200 \mu \mathrm{g} / \mathrm{ml}$. The data were expressed as the mean \pm SD $(n=6)$.

Table 5. Inhibitory activity of Rehmannia glutinosa extracts on various microorganism

\begin{tabular}{|c|c|c|c|c|c|c|c|c|c|c|}
\hline \multirow{4}{*}{ Strains } & \multicolumn{10}{|c|}{ Clear zone (mm) } \\
\hline & \multicolumn{5}{|c|}{ Water extracts } & \multicolumn{5}{|c|}{$40 \%$ ethanol extracts } \\
\hline & \multicolumn{5}{|c|}{ Phenolic content $(\mu \mathrm{g} / \mathrm{ml})$} & \multicolumn{5}{|c|}{ Phenolic content $(\mu \mathrm{g} / \mathrm{ml})$} \\
\hline & 0 & 50 & 100 & 150 & 200 & 0 & 50 & 100 & 150 & 200 \\
\hline Staphylococcus aureus & - & - & - & - & - & - & - & - & - & $9.1 \pm 0.3$ \\
\hline Staphylococcus epidermidis & - & - & - & - & - & - & - & - & - & $9.6 \pm 0.2$ \\
\hline Escherichia coli & - & - & - & - & - & - & - & - & - & trace \\
\hline Propionibacterium acnes & - & - & - & - & - & - & - & - & - & - \\
\hline Streptococcus mutans & - & - & - & - & - & - & - & - & - & - \\
\hline Helicobacter pylori & - & - & - & - & - & - & - & - & - & - \\
\hline
\end{tabular}

-: no inhibition. The data were expressed as the mean \pm SD $(n=6)$. 
Table 6. Inhibition effect of water and ethanol extracts on tyrosinase from Rehmannia glutinosa

\begin{tabular}{|c|c|c|c|c|c|c|}
\hline \multirow{4}{*}{ Sample } & \multicolumn{6}{|c|}{ Inhibition activity (\%) } \\
\hline & \multirow{2}{*}{\multicolumn{2}{|c|}{$\begin{array}{c}\text { Water extracts } \\
\text { Phenolic content }(\mu \mathrm{g} / \mathrm{ml})\end{array}$}} & \multirow{2}{*}{\multicolumn{2}{|c|}{$\begin{array}{l}\text { 40\% Ethanol extracts } \\
\text { Phenolic content }(\mu \mathrm{g} / \mathrm{ml})\end{array}$}} & \multirow{2}{*}{\multicolumn{2}{|c|}{$\begin{array}{c}\text { Positive control (Kojic acid) } \\
\text { Phenolic content }(\mu \mathrm{g} / \mathrm{ml})\end{array}$}} \\
\hline & & & & & & \\
\hline & 100 & 200 & 100 & 200 & 100 & 200 \\
\hline Rehmannia glutinosa & 0 & 0 & $38.4 \pm 2.6$ & $70.2 \pm 5.7$ & $53.2 \pm 3.6$ & $62.4 \pm 5.2$ \\
\hline
\end{tabular}

The data were expressed as the mean $\pm S D(n=6)$.

Table 7. Inhibition effect of water and ethanol extracts on elastase from Rehmannia glutinosa

\begin{tabular}{|c|c|c|c|c|c|c|}
\hline \multirow{4}{*}{ Sample } & \multicolumn{6}{|c|}{ Inhibition activity (\%) } \\
\hline & \multirow{2}{*}{\multicolumn{2}{|c|}{$\begin{array}{c}\text { Water extracts } \\
\text { Phenolic content }(\mu \mathrm{g} / \mathrm{ml})\end{array}$}} & \multirow{2}{*}{\multicolumn{2}{|c|}{$\begin{array}{l}\text { 40\% Ethanol extracts } \\
\text { Phenolic content }(\mu \mathrm{g} / \mathrm{ml})\end{array}$}} & \multirow{2}{*}{\multicolumn{2}{|c|}{$\begin{array}{l}\text { Positive control (Vitamin C) } \\
\text { Phenolic content }(\mu \mathrm{g} / \mathrm{ml})\end{array}$}} \\
\hline & & & & & & \\
\hline & 100 & 200 & 100 & 200 & 100 & 200 \\
\hline Rehmannia glutinosa & $58.4 \pm 6.5$ & $76.2 \pm 2.3$ & $43.3 \pm 3.6$ & $57.2 \pm 5.7$ & $3.2 \pm 0.7$ & $12.9 \pm 0.5$ \\
\hline
\end{tabular}

The data were expressed as the mean \pm SD $(n=6)$.

Table 8. Inhibition effect of water and ethanol extracts on hyaluronidase from Rehmannia glutinosa

\begin{tabular}{|c|c|c|c|}
\hline \multirow{4}{*}{ Sample } & \multicolumn{3}{|c|}{ Inhibition activity (\%) } \\
\hline & Water extracts & $40 \%$ Ethanol extracts & Positive control (Vitamin C) \\
\hline & Phenolic content $(\mu \mathrm{g} / \mathrm{ml})$ & Phenolic content $(\mu \mathrm{g} / \mathrm{ml})$ & Phenolic content $(\mu \mathrm{g} / \mathrm{ml})$ \\
\hline & 100 & 200 & 200 \\
\hline Rehmannia glutinosa & 0 & $5.1 \pm 0.3$ & $14.4 \pm 1.5$ \\
\hline
\end{tabular}

The data were expressed as the mean \pm SD $(n=6)$.

소로서 이들의 활성 억제는 피부 미백과 노화 방지에 매우 중요하다. 본 연구에서는 숙지황 추출물의 tyrosinase 저해 활 성을 측정한 결과 Table 6에서와 같이 물 추출물에서는 tyrosinase 억제효과가 관찰되지 않았으나, $40 \%$ ethanol 추출물 에서는 $200 \mu \mathrm{g} / \mathrm{ml}$ phenolic의 농도에서 positive control인 kojic acid의 $62.4 \%$ 보다 더 높은 $70 \%$ 의 저해효과가 확인되어 우수한 미백효과를 기대할 수 있었다. 저해양상은 농도의존적 인 양상을 나타내었으며 첨가되는 phenolic compound의 양 에 따라 저해효과는 결정될 것으로 판단하였다. Han 등[14]은 민속주의 발효과정에서 tyrosinase저해 활성이 높았으며, 이 는 첨가되는 재료의 플라보노이드 화합물과 같은 phenolic compound에 의한 것으로 판단하였다고 보고한 것과 유사한 결과를 얻을 수 있었다. Lee 등[22]은 제주산 식물을 이용한 tyrosinase 억제 활성을 측정한 결과 $1,000 \mathrm{ppm}$ 의 농도에서 $10.0 \%$ 미만의 효과를 나타낸 결과와 비교하여 천연자원으로 서의 숙지황은 미백 활성이 우수함을 확인할 수 있었다.

\section{주름개선 효과 측정}

인체의 중성구 과립구내에 존재하는 elastase는 진피 내 피 부탄력을 유지하는데 중요한 기질 단백질인 엘라스틴을 분해 하는 효소이며, 다른 중요한 기질 단백질인 콜라겐을 분해할 수 있는 비특이적 가수분해 효소이다. 따라서 elastase 저해제 는 피부 주름을 개선하는 작용을 나타내며[33], elastase 저해
제로 인하여 주름개선의 효과를 기대할 수 있을 것이다. 이러 한 주름 생성과 관련된 elastase 저해 활성 측정 결과를 Table 7에서와 같이 $200 \mu \mathrm{g} / \mathrm{ml}$ phenolic의 농도에서 대조구인 vita$\min \mathrm{C}$ 가 $12.9 \%$ 인데 비하여 물 추출물에서 $76 \%, 40 \%$ ethanol 추출물에서 $57 \%$ 의 높은 elastase 억제효과를 관찰할 수 있었 으며, Kwak 등[21]은 각종 약용식물의 elastase 저해효과가 1 $\mathrm{mg} / \mathrm{ml}$ 의 농도에서 $30.0 \%$ 미만의 저해활성을 나타낸다고 보 고한 것과 비교하면, 숙지황 추출물의 elastase 저해활성이 매 우 높은 것을 알 수 있었다. 따라서 숙지황 추출물은 주름개선 을 위한 미용식품이나 주름개선 기능성화장품에 적용이 가능 할 것으로 판단하였다.

\section{Anti-inflammation 효과 측정}

고분자 다당인 히아루론산(hyaluronic acid, $\mathrm{HA}$ )은 진피층 의 섬유아세포로부터 산출되어, 표피, 진피에 있어서 주요한 세포외 매트릭스로서 glucuronic acid와 glucosamine이 반복 해서 연결된 점액성 mucopolysaccharide이다. 또한 HA은 염 증 형성의 중요 요소인 macrophage의 phagocytic ability를 저해하는 한편, $\mathrm{HA}$ 분해 산물 혹은 저분자 $\mathrm{HA}$ 는 상처 치유 과정에서 inflammation, fibrosis collagen deposition을 증가 시키는 것으로 알려져 있으며, 이는 결국 고분자 $\mathrm{HA}$ 의 분해효 소인 hyaluronidase (HAase)의 저해에 의해 HA의 고분자 형 태를 유지하게 함으로서 항염증 효과를 기대할 수 있다[13]. 
숙지황 추출물에 대한 HAase 저해활성을 측정 결과 Table 8에 서와 같이 숙지황 물 추출물에서는 HAase 저해활성을 전혀 나타내지 않았으며, $40 \%$ ethanol 추출물에서도 $200 \mu \mathrm{g} / \mathrm{ml}$ phenolic의 농도에서만 약 $5 \%$ 의 매우 낮은 HAase 저해활성을 나타내어 항염증 효과나 아토피 억제효과를 기대하기는 어려 울 것이라 판단되었다.

이상의 연구 결과에서와 같이 숙지황 추출물은 우수한 항산 화 및 항고혈압 활성을 이용한 생활습관병 예방 건강 기능성 식품으로의 활용이 가능하리라 생각되며, 피부상재균 억제효 과, 미백 및 주름개선효과 등도 우수하여 복합 기능성 화장품 원료로 산업화에 적용할 수 있을 것이라 판단되었다.

\section{감사의 글}

이 논문은 2010년 경북대학교 학술연구지원금에 의하여 연 구되었으며 이에 감사드립니다.

\section{References}

1. Andarwulan, N. and Shetty, K. 1999. Phenolic content in differentiated tissue cultures of untransformed and Agrobacterium-transformed roots of anise(Pimpinella anisum L.). J. Agric. Food Chem 47, 1776-1780.

2. Blios, M. S. 1958. Antioxidant determination by the use of a stable free radical. Nature 26, 1199-1200.

3. Boo, H. O., Hwang, S. J., Bae, C. S., Park, S. H. and Song, W. S. 2011. Antioxidant activity according to each kind of natural plant pigment. Kor. J. Plant Res. 24, 105-112.

4. Buege, J. A. and Aust, S. D. 1978. Microsomal lipid peroxidation. Method Enzymol. 105, 302-310.

5. Chen, L. Z., Feng, X. W. and Zhou, J. H. 1995. Effects of Rehmannia glutinosa polysaccharide b on T-lymphocytes in mice bearing sarcoma 180. Chung. Kuo. Yao. Li. Hsueh Pao. 16, 337-340.

6. Cho, S. I. 2003. Antioxidative effects of Rehmanniae Radix Preparata on toxic agent induced kidnet cell injury. Kor. J. Herbology 18, 119-126.

7. Choi, S. I., Lee, Y. M. and Heo, T. R. 2003. Screening of hyaluronidase inhibitory and free radical scavenging activity in vitro of traditional herbal medicine extracts. Kor. J. Biotech Bioeng. 18, 282-288.

8. Chung, H. J. 1989. Studies on variation of constituents and enzyme activities of Rehmannia Radix by processing. Department of Pahamacy, Graduate school of Sookmyung Woman's University, Korea. pp. 1-12.

9. Conner, D. E. and Beuchat, L. R. 1984. Sensitivity of heat-stressed yeasts to essential oils of plants. Appl. Environ. Microbial. 47, 229-233.

10. Cushman, D. W., Cheung, H. S., Sabo, E. F. and Ondetti, M. A. 1977. Design of potent competitive inhibitors of angiotensin-converting enzyme. Carboxylalkanoyl and mercaptoalka noyl amino acids. Biochemistry 16, 5484-5491.
11. Duval, B. and Shetty, K. 2001. The stimulation of phenolics and antioxidant activity in pea (Pisum sativum) elicited by genetically transformed anise root extract. J. Food Biochem 25, 361-377.

12. Folin, O. and Denis, W. 1912. On phosphotungastic-phosphomolybetic compounds as color reagents. J. Biol. Chem 12, 239-249.

13. Ghosh, P. 1994. The role of hyaluronic acid (hyaluronan) in health and disease: interactions with cells, cartilage and components of synovial fluid. Clin. Exp. Rheumatd. 12, 75-82.

14. Han, K. H., Lee, J. C., Kim, J. H. and Lee, J. S. 2002. Manufacture and physiological functionality of Korean traditional liquor by using purple-fleshed sweet potato. Kor. J. Food Sci. Technol. 34, 673-677.

15. Jang, M. S., Yang, W. M., Yu, T. W., Kim, D. R., Park, E. H., Ko, E. B., Choi, M. J., Kim, H. Y., Oh, J. H., Shin, K. J., Yoon, J. W. and Park, S. K. 2007. Antioxidant effects of Rehmanniae Radix Preparat in GC-1 cell. Kor. J. Herbology 22, 81-86.

16. Jeong, H. J. and Kim, I. H. 1990. Comparative studies om the antidiabetic activities of Rehmannia Radices. J. Pharm Sci. 4, 22-31.

17. Ju, I. S. and Cho, Y. J. 2009. Purification and identification of phenol compounds with inhibitory activity on Helicobacter pylori from Rhododendron mucronulatum Flos. extracts. J. Life Sci. 19, 1125-1131.

18. Kim, E. Y., Baik, I. H., Kim, J. H., Kim, S. R. and Rhyu, M. R. 2004. Screening of the antioxidant activity of some medicinal plants. Kor. J. Food Sci. Technol. 36, 333-338.

19. Kim, J. H. 2006. Biological activity of phenolic compound from Herb and Oriental medicinal resource. Kyungpook national university MS thesis, Korea, p. 17-22.

20. Kim, S. J., Lim, J. H., Lee, R. S. and Lee, J. S. 1996. Extraction and a characteristics of a purple sweet potato pigment. Kor. J. Food Sci. 28, 345-347.

21. Kwak, Y. J., Lee, D. H., Kim, N. M. and Lee, J. S. 2005. Screening and extraction condition of anti-skin aging elastase inhibitor from medicinal plants. Kor. J. Med Crop. Sci. 13, 213-216.

22. Lee, N. H., Yang, H. C., Bu, H. J., Jung, D. S., Lee, S. J. and Riu, K. Z. 2001. Screening of the tyrosinase inhibition and hyaluronidase inhibition activities and radical scavenging effects using plants in Cheju. Kor. J. Pharmaco. 32, 175-180.

23. Lee, H. 2011. Effects of Lxeris dentata extracts on lowering lipid and antioxidation. Kor. J. Plant Res. 24, 55-60.

24. Moon, S. H. and Lee, Y. J. 2001. Studies on the digestive function of Rehmanniae Radix produced by different processes. Kor. J. Herbology 16, 65-77.

25. Park, J. B. 1993. Effects of Rehmannia Radix aqua-acupuncture at the meridian point BL 23 on the renal function in two-kidney one goldblatt hypertensive rats. Department of oriental medicine, graduate school of Wonkang University, Korea, pp. 2-9.

26. Pellegrin, N., Roberta, R., Min, Y. and Catherine, R. E. 1998. Screening of diatry carotenoids and carotenoid-rich fruit ex- 
tracts for antioxidant activities applying 2,2'-azinobis(3-ethylenebenzothiazoline-6-sulfonic acid)radical cation decolorization assay. Method Enzymol. 299, 379-389.

27. Soffer, R. L. 1976. Angiotensin-converting enzyme and the rela gulation of vasoactive peptides. Ann. Rev. Biochem 45, 73-78.

28. Storch, J. and Feber, E. 1988. Detergent-amplified chemilum-inescence of lucigenin for determination of superoxide anion production by NADPH oxidase and xanthine oxidase. Anal. Biochem 169, 262-267.

29. Stirpe, F. and Crote, E. D. 1969. The regulation of rat liver xanthine oxidase. J. Biol. Chem 244, 3855-3858.

30. Tomoda, M., Miyamoto, H. and Shimizu, N. 1994. Structural features and anti-complementary activity of rehmannan SA, a polysaccharide from the root of Rehmannia glutinosa. Chem Pharm Bull. 42, 1666-1668.

31. Tomoda, M., Miyamoto, H., Shimizu, N., Gonoda, R. and Ohara, N. 1994. Characterization of two polysaccharides having activity on the reticuloendothelial system from the root of Rehmannia glutinosa. Chem Pharm Bull. 42, 625-629.
32. Tomoda, M., Miyamoto, M., Shimizu, N., Gonoda, R. and Ohara, N. 1994. Two acidic polysaccharides having reticuloendothelial system-potentiating activity from the raw root of Rehmannia glutinosa. Biol. Pharm Bull. 17, 1456-1459.

33. Tsuji, N., Moriwaki, S., Suzuki, Y., Takema, Y. and Imokawa, G. 2001. The role of elastases secreted by fibroblasts in wrinkle formation: implication through selective inhibition of elastase activity. Phytochem Photobiol. 74, 283-290.

34. Xu, M. L., Wang, L. and Wang, M. H. 2011. The antioxidant and anticancer effects of $\mathrm{MeOH}$ extract of Liriodendron tulipifera. Kor. J. Plant Res. 24, 23-29.

35. Yagi, A., Kanbara, T. and Morinobu, N. 1986. The effect of tyrosinase inhibition for aloe. Planta. Medica. 3981, 517-519.

36. Yang, Y. J., Kim, H. J., Kang, S. H. and Kang, S. C. 2011. Screening of natural herb resources for antioxidative effects in Korea. Kor. J. Plant Res. 24, 1-9.

37. Zielinski, H. and Kozlowska, H. 2000. Antioxidant activity and total phenolics in selected cereal grains and their different morphological fractions. J. Agric. Food Chem 48, 20082016.

\section{초록 : 숙지황(Rehmannia g/utinosa) 추출물의 생리활성 \\ 조영제* \\ (경북대학교 식품공학부/식품생물산업연구소)}

숙지황(Rehmannia glutinosa)으로부터 유용성분 추출은 $40 \%$ 에탄올 추출물에서 $5.1 \pm 0.2 \mathrm{mg} / \mathrm{g}$ 으로 가장 높은 phenolic compound 함량을 나타내었다. 숙지황 추출물의 항산화활성은 전자공여능의 경우 물 추출물과 $40 \%$ ethanol 추출물 모두에서 85 93\% 의 높은 전자공여능이 확인되었으며, ABTS radical cation decolorization의 경 우 물 추출물과 $40 \%$ ethanol 추출물이 $55 \sim 62 \%$ 의 비슷한 수준의 항산화효과를 효과를 나타내었고, antioxidant protection factor $(\mathrm{PF})$ 는 $200 \mu \mathrm{g} / \mathrm{ml}$ 의 농도에서 물 추출물과 $40 \%$ ethanol 추출물 모두에서 $1.6 \sim 1.9 \mathrm{PF}$ 의 높은 항산화력이 확인되었고, TBARs는 물 추출물과 $40 \%$ ethanol 추출물이 비슷한 수준의 항산화효과를 효과를 나타 내는 것으로 측정되었다. 숙지황 추출물의 고혈압억제효과는 물 추출물에서 $87.2 \%, 40 \%$ ethanol 추출물에서 $81.1 \%$ 의 저해활성을 나타내었다. 관절염억제효과는 매우 낮게 측정 되었으며, 피부상재균에 대한 항균효과는 확 인되었다. 숙지황 추출물의 tyrosinase 저해 활성은 $40 \%$ ethanol 추출물에서 $70 \%$ 의 높은 저해효과가 확인되어 미백효과를 기대할 수 있었다. 주름 생성과 관련된 elastase 저해 효과는 물 추출물에서 $76 \%$, ethanol 추출물 $57 \%$ 의 높은 elastase 억제효과를 관찰할 수 있었다. 숙지황 추출물에 대한 hyaluronidase 저해활성은 $40 \%$ ethanol 추출물에서만 $200 \mathrm{\mu g} / \mathrm{ml}$ phenolic의 농도에서 약 $5 \%$ 의 매우 낮은 hyaluronidase 저해활성을 나타내었다. 